Original paper

\title{
Geophysical research on structure of partly eroded maar volcanoes: Miocene Hnojnice and Oligocene Rychnov volcanoes (northern Czech Republic)
}

\author{
Zuzana SKÁCELOVÁ ${ }^{*}$, Vladislav RAPPRICH${ }^{1}$, Jan VALENTA², Filip HARTVICH ${ }^{2}$, Josef \\ ŠRÁMEK'1, Miroslav RADOŇ³ ${ }^{3}$ Renata GAŽDOVÁ2, Lucie NOVÁKOVÁ2, Petr KOLÍNSKÝ2, \\ Zoltán PÉCSKAY4
}

\author{
${ }^{1}$ Czech Geological Survey, Klárov 3, 11821 Prague 1, Czech Republic; zuzana.skacelova@geology.cz \\ ${ }^{2}$ Institute of Rock Structure and Mechanics, Academy of Sciences of the Czech Republic - v.v.i., V Holešovičkách 41, 18209 Prague 8 , \\ Czech Republic \\ ${ }^{3}$ Regional Museum Teplice, Zámecké nám. 14, 41513 Teplice, Czech Republic \\ ${ }^{4}$ Institute of Nuclear Research of Hungarian Academy of Sciences, Bem tér 18/C, H-4001 Debrecen, Hungary \\ * Corresponding author
}

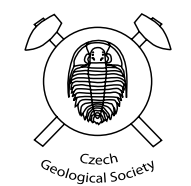

\begin{abstract}
The internal structure of two partly eroded maar-diatreme volcanoes in the northern Czech Republic has been studied by combination of ground magnetometry, ground gravity measurements and multi-electrode resistivity profiling. Hnojnice and Rychnov maars were selected as maar-diatreme volcanoes described from surface geological survey and representing different country rock settings. The Hnojnice diatreme penetrates thick sequence of Upper Cretaceous marine sediments, whereas the Rychnov maar is situated within the crystalline rocks. This research improved the knowledge on geometry and dimensions of the studied diatremes.

The basaltic feeder dyke of the Hnojnice maar has been discovered. The main dyke is located approximately in the axis of the maar. The dyke was detected within, and extending northwest of, the maar. According to the geophysical survey, several branches are associated with the main feeder dyke, one of them - funnel shaped ring dyke - marks the outer limit of the diatreme. Other small branches (or larger basaltic clasts) are situated within the diatreme breccias.

Basaltic dyke penetrating the Rychnov maar has been quarried in past. It was emplaced asymmetrically at the southwestern margin of the diatreme. According to the magnetometric survey, the dyke extends further to the northwest if compared with originally supposed extent. The dyke, and hence also the entire Rychnov maar, has been dated by the K-Ar method on bulk-rock to Late Oligocene $(28.4 \pm 1.3 \mathrm{Ma})$.
\end{abstract}

Keywords: Maar-diatreme volcano, ground magnetometry, ground gravity measurements, geoelectrical imaging, Bohemian Massif Received: 26 April 2010; accepted: 10 September 2010; handling editor: V. Kachlik

\section{Introduction}

Mafic magmas usually rise to the Earth's surface in small portions. Small monogenic volcanoes predominate among the volcanic landforms on the continents (e.g., Fisher and Schmincke 1984). With respect to the content of volatiles dissolved in the melt, absence/presence of the external water and the depth of magma-water interaction, several types of volcanic forms can be produced:

- lava cone or small shield volcano - no volatiles, no external water,

- spatter cone - very little volatiles, no external water,

- cinder cone - little volatiles, no external water,

- tuff cone - independent of volatiles, surface or shallow sub-surface external water,

- maar - independent of volatiles, sub-surface external water.
Even though the eruptions of monogenic volcanoes affect only relatively small area, the large number of these volcanoes and their eruptions make the understanding of small volcanic systems very urgent. Many fields of monogenic volcanoes occur in areas of active volcanism, but structure and processes related to small volcanic edifices can be studied on ancient volcanic sequences as well.

Maar volcanoes are studied intensively worldwide, with special emphasis on eruption energy and hazards related to volcanic activity (e.g., Lorenz 2007; Lorenz and Kurszlaukis 2007). Lorenz et al. (2003) defined four principal facies of a maar-diatreme volcano: a) maar crater filled by the so-called maar facies, b) inward bedded upper diatreme facies, c) unbedded lower diatreme facies, and d) root zone (Fig. 1). The maar volcanoes produce negative topography in the landscape and usually become buried by subsequent sedimentation. Even the diatremes are often not harder than their country rocks and, there- 


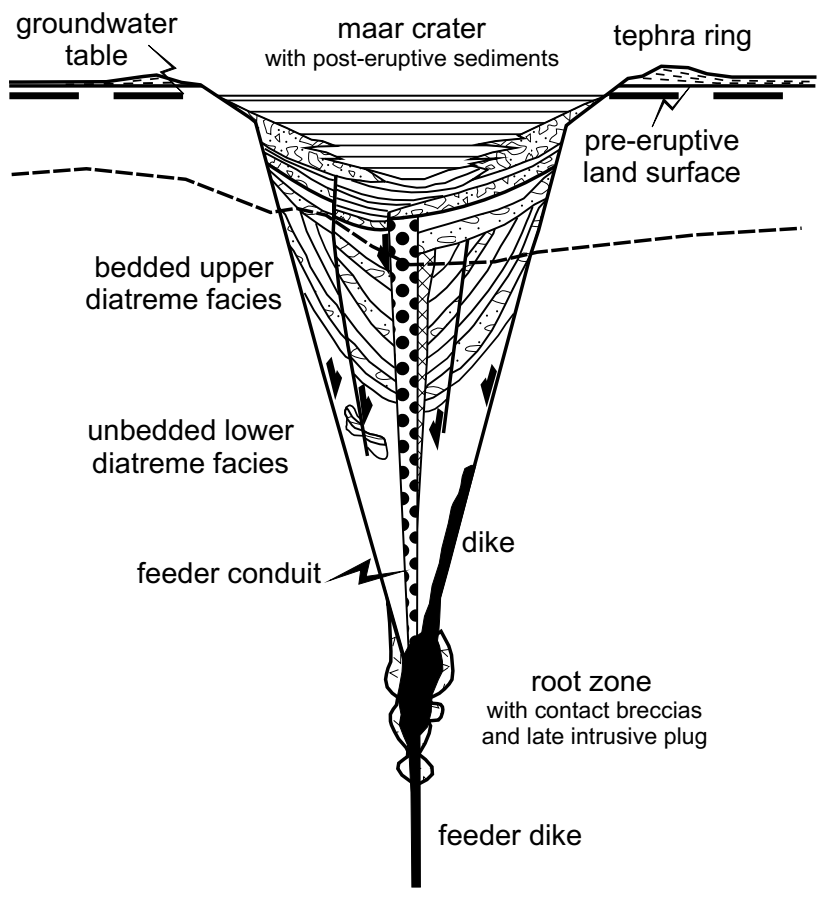

Fig. 1 Ideal section through a typical maar-diatreme volcano (adapted after Lorenz et al. 2003). Thick dashed line approximates the current surface level at Hnojnice (roughly on geoelectrical profile 2 - see Fig. 4).

fore, are only exceptionally exposed by selective erosion and thus available to geological studies. For that reason, research of maar-diatreme volcanoes often has to rely on geophysical methods.

For instance, Emilia et al. (1977) discovered complex setting of coherent volcanic rocks, including lava-lake and feeding system intrusions, within the maar sediments and diatreme breccia of the Haro Maja maar in Ethiopia using the magnetometry and electric resistivity measurements. The 3D geoelectric tomography of the Baruth maar in SE Germany was used for reconstruction of its internal structure and optimal location of subsequent borehole focused on palaeoclimatologic studies (Brunner et al. 1999). Different scenarios in evolution of maar volcanoes have been assessed by ground geophysical survey (gravity and magnetic - Cassidy et al. 2007) in the Auckland volcanic field (New Zealand). A peculiar, inclined geometry of the feeder system of the Joya Honda maar (México) with directed eruption was described by Loera et al. (2008) using ground gravity and magnetic measurements. The ground geophysical methods have been successfully used for detection of a supposed Pleistocene maar volcano in western Bohemia (Mrlina et al. 2009). A dependence of maar-diatreme volcanoes geometry on the country rock character was described by Lorenz (2003).

Monogenic volcanoes have formed during Permian and Cenozoic in the Bohemian Massif. These were subjected to erosion, which occasionally dissected their internal structure and enabled studies, which would not be possible in active volcanic fields or in fresh volcanoes not affected by erosion or exploitation.

Partly eroded scoria- and tuff cones in Miocene volcanic fields of the Czech Republic have been studied recently (e.g., Rapprich et al. 2007; Cajz et al. 2009a). Another monogenic volcanic form, which was formerly believed to be frequently present in the Bohemian Massif (e.g., Kopecký 1987), is a maar-diatreme volcano. Many of the volcanic breccias originally described as diatreme facies have been reinterpreted as scoria cones (Cajz et al. 2009a) or lahar deposits (Rapprich 2007). On the other hand, there are several real phreatomagmatic breccias representing conduit systems of maar volcanoes and maar volcano remnants preserved within, and along the edges of, the Eger Graben (Suhr 1999). We selected two representative partly eroded maar-diatreme volcanoes with well-described surface geology to investigate their deeper structure using geophysical methods. The obtained results demonstrate how complex geophysical image can be generated by a relatively simple (monogenic) volcano.

\section{Geological setting}

Cenozoic volcanic activity of the Bohemian Massif belongs to the suite of Circum-Mediterranean anorogenic magmatism (sensu Lustrino and Wilson 2007). It started in Late Cretaceous (Ulrych and Pivec 1997), culminated in Oligocene (Cajz 2000; Rapprich and Holub 2008) and lasted until Pleistocene (Ulrych and Pivec 1997). The magmatic activity was concentrated within the Eger Graben, where two prominent volcanic complexes have formed: Doupovské hory Volcanic Complex in the west (DHVC, Oligocene to Early Miocene - Rapprich and Holub 2008) and České středohorrí Volcanic Complex to the east (CSVC, Oligocene to Late Miocene - Ulrych et al. 1999; Cajz 2000; Ulrych et al. 2002; Cajz et al. 1999, 2009a). Apart from the two main volcanic complexes, numerous scattered isolated volcanoes formed both within, and outside, the Eger Graben. Probably the highest frequency of the off-graben monogenic volcanoes occurs along the Lusatian Fault (e.g., Vaněčková et al. 1993; Rapprich et al. 2007 - Fig. 2).

The two maar volcanoes were selected for the geophysical research because they are isolated; the intricate geophysical image within the volcanic complexes would make the geophysical data hardly readable.

The Hnojnice diatreme (50²6'02'N, 013 ${ }^{\circ} 53^{\prime} 05^{\prime \prime} \mathrm{E}-$ Fig. 3), situated south of the Hnojnice village, penetrates the Upper Cretaceous marine sediments on the southwestern periphery of the CSVC. The vent breccia of the Hnojnice diatreme was first discovered by Malkovský 


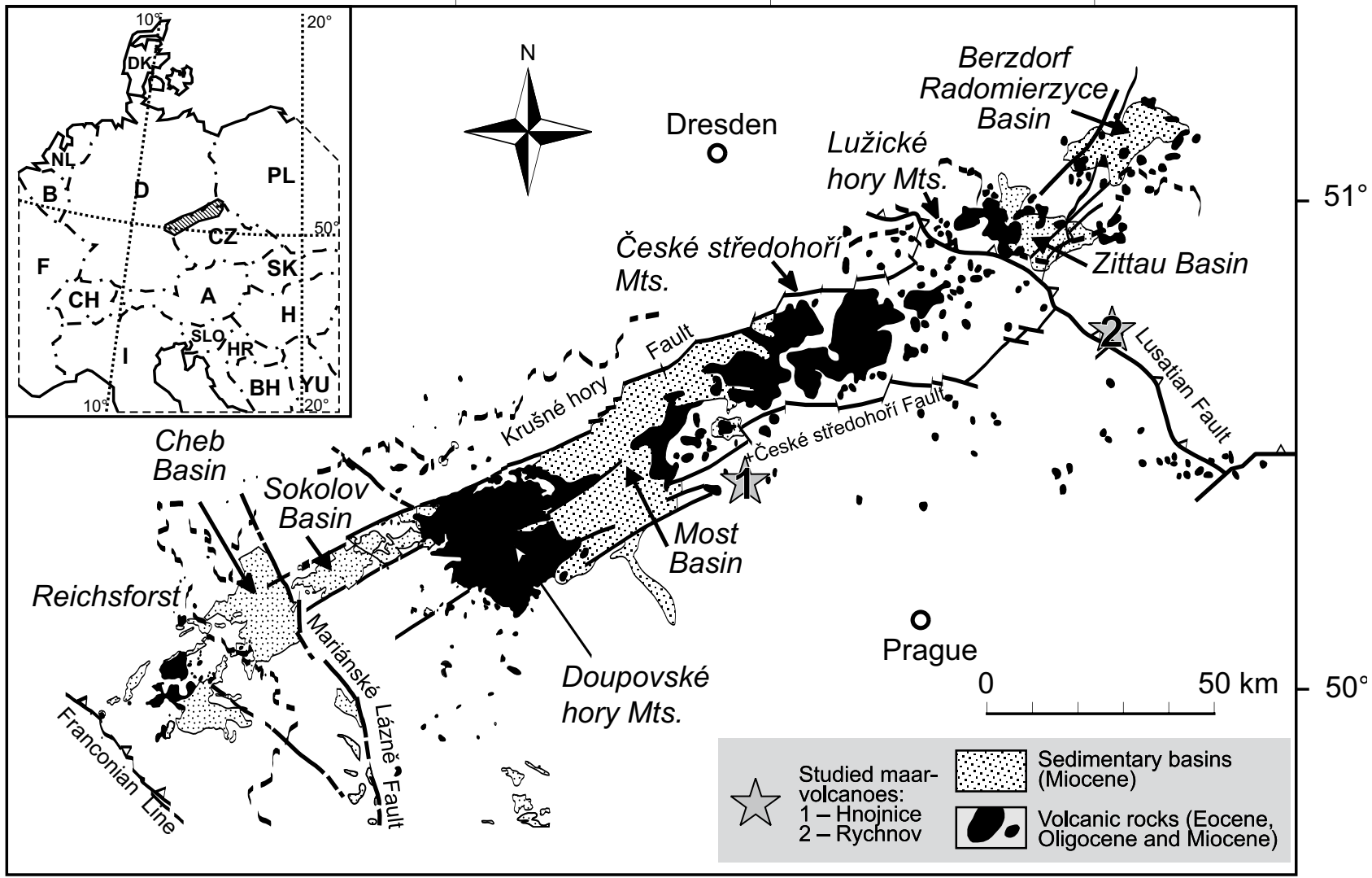

Fig. 2 Location of studied sites at the southern edge of the Eger Rift.

(1953) and described as basaltic breccia with xenoliths of Cretaceous sediments. Shortly after its discovery, this locality became a Protected Natural Site. The origin of the Hnojnice breccia was interpreted by Kopecký et al. (1967) as a phreatomagmatic breccia of a maar-diatreme volcano. Since that time, no study has been done on this spectacular volcanic feature. The diatreme makes croissant-like morphology (Fig. 4). Perhaps surprisingly, this morphology does not correspond to the superficial tuff ring of a maar-diatreme volcano. In the abandoned quarry on the southern edge of the diatreme, inward dipping beds of the phreatomagmatic breccias are clearly visible (Fig. 5). Applying the facies definition by Lorenz et al. (2003), the breccia exposed at Hnojnice corresponds to the upper diatreme facies. The phreatomagmatic breccia consists of larger marlstone xenoliths $(10-50 \mathrm{~cm})$ enclosed in matrix of small (about $1 \mathrm{~cm}$ ) marlstone clasts with little volcanic admixture. The radial cracks extending from the larger clasts into the tuff make a structure termed Kamenná slunce ("Stone Suns") - for which is this locality famous and protected.

Unfortunately, no juvenile magmatic material suitable for the age determination was found within the Hnojnice breccia. The relatively weak erosion of this soft volcano

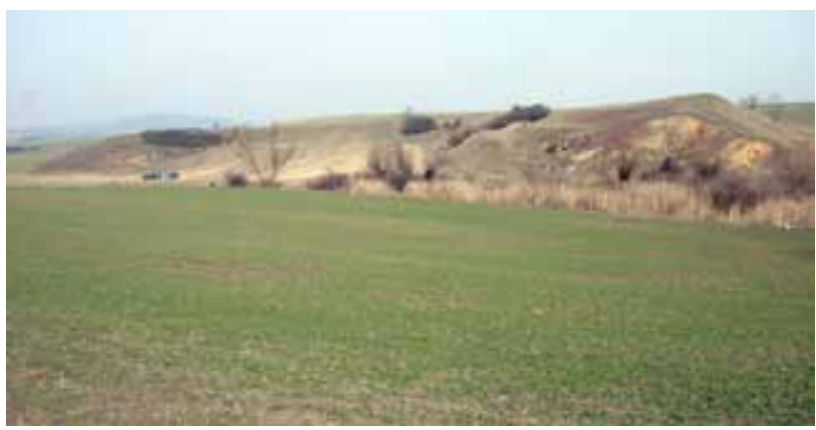

Fig. 3 View on the Hnojnice diatreme from the Koštice-Libčeves road.

situated in soft Cretaceous sediments could be compared with slightly eroded monogenic cones of late Miocene age ( $9 \mathrm{Ma}-$ Cajz et al. 2009a) located some $5.5 \mathrm{~km}$ to the northwest. Remnants of volcanic forms of the previous formations (c. 30 and c. 20 Ma sensu Cajz 2000) tend to be eroded to much deeper level, whereby feeder dyke systems are exposed.

The Rychnov maar $\left(50^{\circ} 40^{\prime} 45^{\prime \prime} \mathrm{N}, 015^{\circ} 08^{\prime} 20^{\prime \prime} \mathrm{E}\right.$ - Fig. 6) is located near the Lusatian Fault (Fig. 2). It penetrates crystalline rocks of the Radčice Unit (Krkonoše-Jizera crystalline block). Chlorite-sericite and 


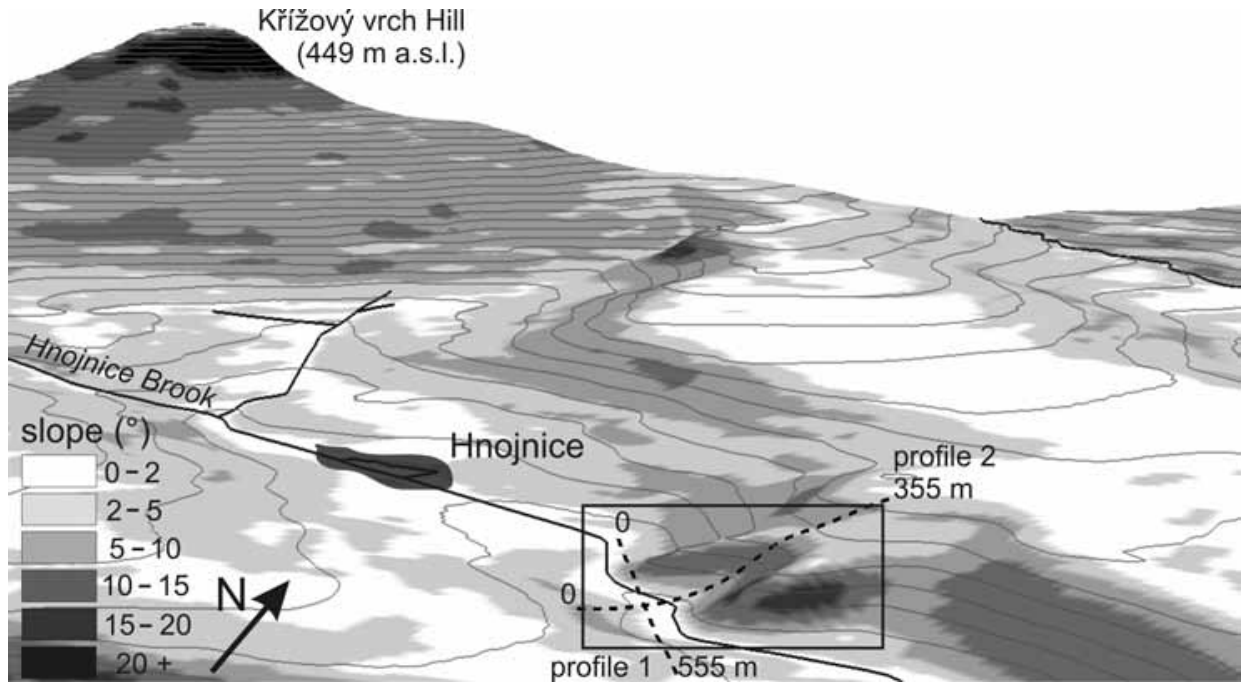

Fig. 4 A 3D overview of the studied site of the Hnojnice diatreme - indicated by the rectangle. The various greyscales correspond to the slope dip. The figure also demonstrates the position of the geoelectric profiles 1 and 2 .

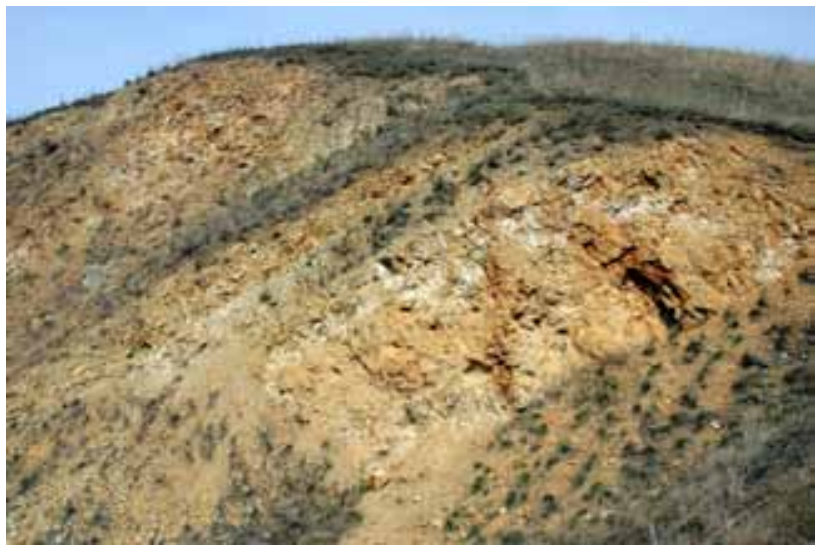

Fig. 5 Inward dipping beds of phreatomagmatic breccia of Hnojnice diatreme corresponding to the upper diatreme facies (sensu Lorenz et al. 2003).

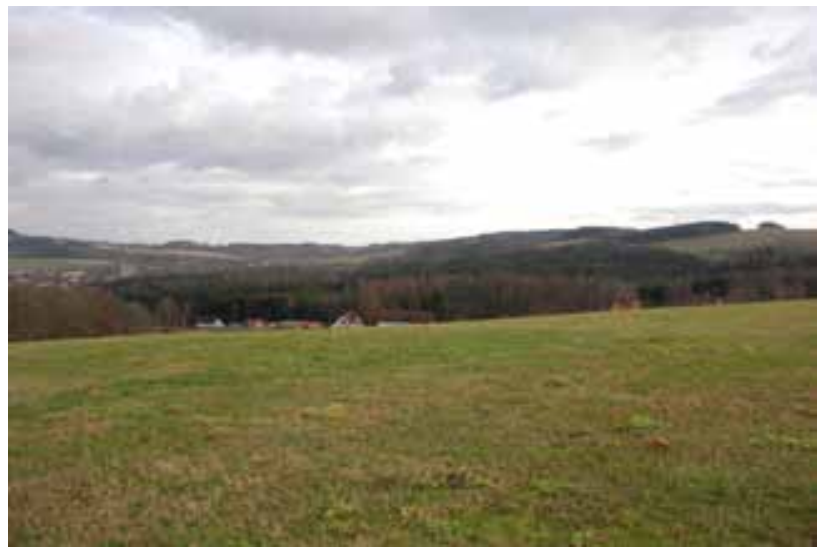

Fig. 6 View over the depression of the Rychnov maar crater.

sericite-chlorite phyllites (bulk-rock magnetic susceptibility 100-200 × $10^{-6} \mathrm{SI}$ ) with basic metatuffs (bulk-rock magnetic susceptibility $200-400 \times 10^{-6} \mathrm{SI}$ ) and metadol- erites occur in the maar surroundings. To the south, the Radčice Unit is overlain by sericite phyllite with limestone and quartzite intercalations, assigned to the Poniklá Group by Kachlík and Patočka (1998). Small body of mylonitized porphyroclastic metagranite straddles probably the boundary between the above-mentioned units, which may be modified by local thrusts in the west.

The Rychnov maar was the first maar volcano recognized in the Bohemian Massif (Watznauer 1935). The maar-crater interpretation of this depression was supported by two boreholes (I: $81 \mathrm{~m}$ deep; and II: $148 \mathrm{~m}$ deep). The maar filling is cut by one larger dyke at the southern margin (opened by a large quarry operating in 1930's - Watznauer 1935) and smaller dyke(s) at the northern margin. The findings of coal fragments in maar fillings in 1930's probably inspired the prospecting works in 1950's accompanied with another three boreholes (Ry-1: $33.5 \mathrm{~m}$ deep; Ry-2: $32 \mathrm{~m}$ deep; and Ry-3: $33 \mathrm{~m}$ deep Řeháková and Václ in Čadek and Václ 1959). According to the boreholes, the maar is filled with clays intercalated with diatomite layers and lignite lenses. Coarser grained and ill-sorted sediments (sands and gravels) alternating with clays characterize the rim of the maar filling. The borehole "I" reached massive basalt at the depth of 68.6 $\mathrm{m}$ and did not penetrate it, even though it finished at 81.3 $\mathrm{m}$. The borehole "II" reached altered basalt at $\sim 147 \mathrm{~m}$ and fresh basalt at $148 \mathrm{~m}$. The later works penetrated only the uppermost $10 \mathrm{~m}$ of the crater fill with ill-sorted gravels or alternation of gravels, sands and clays (e.g., Bureš et al. 1973). Nowadays, only an abandoned gravel pit in the maar poorly exposes ill-sorted gravels with ill-rounded phyllite fragments set in clayey matrix. The genetic interpretation of these gravels would require a better outcrop with sedimentary geometries and structures exposed, but still the poor sorting of the sediments does not seem to be related to a fluvial sedimentation. 
The occurrence of thick sedimentary cover at Rychnov motivated also the gravity research. An intense but spatially limited negative anomaly was detected by the gravity research in 1980's. The values of the anomaly reached $-6.5 \mathrm{mGal}$ in the central part and the model depth of the crater (calculated from gravity data) was estimated at $800 \mathrm{~m}$ (Šrámek et al. 1989).

\section{Methods}

The maar-diatreme volcanoes tend to be significant sources of negative gravity anomalies (e.g. Schulz et al. 2005). As presented in this paper, the magnetic image is strongly dependent on the character of country rocks. A combination of the gravimetric and magnetic research has been employed successfully to study buried maar volcanoes in Upper Silesia by Lindner et al. (2006). Therefore, we combined several geophysical methods in research of maar-diatreme volcanoes in northern Bohemia.

\subsection{Magnetic survey}

Magnetic field measurements were carried out by the proton magnetometer PM-2 (Geofyzika Brno). At Hnojnice were measured 240 points on 14 profiles, which covered an area of $c .200 \times 200 \mathrm{~m}$. The step of the measured points was $10 \mathrm{~m}$, the sensor level was $2 \mathrm{~m}$. At Rychnov near Jablonec nad Nisou were measured 102 points, which systematically covered an area of $c .1 .5 \times 1.5 \mathrm{~km}$. The $\Delta \mathrm{T}$ value was corrected for daily variation (recurring measurement). The daily variation was inconsiderable if compared with amplitudes of measured anomalies. The accuracy of magnetic measurement was $\pm 2 \%$. The data and their coordinates were compiled by the SURFER software (Golden Software Inc.) to the contour maps of $\Delta \mathrm{T}$ in the $10 \times 10 \mathrm{~m}$ grid for Hnojnice and $100 \times 100 \mathrm{~m}$ for Rychnov. Kriging was used as the gridding method. The magnetic susceptibility was measured on rock handspecimens in the field by the magnetic susceptibility meter KT-5.

\subsection{Gravity survey}

The gravity survey was carried out on two perpendicular profiles crossing the diatreme at Hnojnice (Fig. 4). The station spacing varied on the profiles from 5 to 20 meters. About 50 data points were measured in this area. The measurement was carried out using the Scintrex CG-5 gravity meter. Recorded data were corrected for the drift of the instrument and for the local topography to produce the Bouguer anomalies.

The next step was the regional gravity field removal in order to obtain residual anomalies. This is a difficult task. In the case of the profile 2, we have measured points located far outside the maar boundaries. Then we have used these to estimate the regional field using the linear approximation. This was not possible for the profile 1 as we have crossed a fault zone (see the resistivity section $\mathrm{x}$-coordinates 40-60 in Fig. 8). Since the position of the fault zone has not been known prior to the survey design, we could not have taken its presence into account. Hence the aforementioned procedure could not had been employed for residual field estimation. Instead we have used the SE-most points outside the diatreme and an estimate in the NW - the data for the point 116, just before the rapid decrease caused by the fault zone and consequent change in lithology. Therefore the residual anomaly for the profile 1 is less well constrained.

As a next step, the residual data were modelled numerically using the GeoModel 2.5D code by G. R. J. Cooper from the University of the Witwatersrand (Cooper 2010). Since the resolution of the gravity data at depths of $c$. 200 meters is very rough, the deepest parts of our models must be taken only as one of many possibilities.

The gravity survey of the Rychnov maar was based on network of 16 measured points with density about 3-4 points per $\mathrm{km}^{2}$. The archived free data of CGS-Geofond were used as published by Šrámek et al. (1989).

\subsection{Geoelectrical survey}

The geoelectrical survey was carried out on the same profiles as the gravity survey. The multi-electrode resistivity method was selected from the wide range of possible approaches. This method has a relatively high depth range (about 60 meters in the current configuration) and can produce 2D sections with a sufficient detail. The data were collected using the ARES resistivity meter (GF Instruments). The electrode spacing on the profiles was 5 meters. The measured data were further inverted using the Res2dinv software to produce 2D resistivity models (Loke and Barker 1996).

The inner margin of the maar is more compact then the surroundings and forms a topographic elevation. These more compact and less weathered rocks can be mapped as a zone of increased resistivities. The individual basalt dykes are revealed by vertical high-resistivity anomalies.

\subsection{K-Ar dating}

Unfortunately, there is no magmatic material available within the Hnojnice diatreme. On the other hand, the basaltic dyke penetrating the Rychnov maar has been quarried in the past. The abandoned quarry exposes basanite with local glassy facies (limburgite), which has been newly dated as a bulk-rock using $\mathrm{K}$-Ar method in the ATOMKI laboratories (Debrecen, Hungary). 
Potassium concentration was measured by the CORNING 480 digitised flame photometer with Li internal standard. The inter-laboratory standards Asia 1/65, LP-6, HD-B1 and GL-O were used to check the analysis. Argon was extracted by high frequency induction heating and ${ }^{38} \mathrm{Ar}$ spike was introduced to the system from a gas pipette before the degassing started. The isotopic ratios were measured on a $15 \mathrm{~cm}$ radius magnetic sector-type mass spectrometer in static mode. Details on the instruments, the applied methods and results of calibration have been published e.g. by Balogh (1985). Atomic constants suggested by Steiger and Jäger (1977) were used for the calculation of ages. The analytical errors are quoted at the $68 \%$ confidence level (one standard deviation). For stratigraphic classification, we refer to the International Stratigraphic Chart (International Commission on Stratigraphy 2010).

\section{Results}

\subsection{Hnojnice diatreme}

Presence of the Hnojnice diatreme was proved by all the geophysical methods applied. The most detailed image of the shallow subsurface structure was produced by the multi-electrode resistivity method. However, the depthreach of this method is limited. Hence the best way to interpret the geophysical data is probably to model the shallow subsurface according to the geoelectrics and then continue to the depth using the data from gravity and magnetic measurements.

\subsubsection{Ground magnetic measurements}

As the magnetometry represents fast method covering easily the entire study area, we were able to produce detailed magnetic map of the Hnojnice diatreme (Fig. 7). The magnetic image displays a significant elongated positive anomaly reaching $1400 \mathrm{nT}$. The trend of this anomaly (NW-SE) follows the Hnojnice brook. The elongated anomaly is associated with an appendix in the central part of the diatreme. Two smaller isolated positive anomalies were detected, where the western and southern margins of diatreme are supposed to be located.

The Cretaceous sediments at the Hnojnice locality have the magnetic susceptibility of $c$. $10-30 \times 10^{-6} \mathrm{SI}$, identical to the xenoliths in the "Stone Suns". The higher values are encountered in the breccias (120-160 $\times$ $10^{-6} \mathrm{SI}$ ) and occasional basaltic boulder (18 600-28 500 $\left.\times 10^{-6} \mathrm{SI}\right)$. This magnetic contrast is very strong, especially between Cretaceous rocks and the basaltic dyke, which warrants the necessary variation in the magnetic field.

\subsubsection{Multielectrode resistivity method}

The multielectrode resistivity method can precisely image the topmost part of the structure, close to the surface. The inverted 2D models give distribution of resistivities along the profile (Fig. 8). In case of the Hnojnice diatreme, the low resistivities correspond to the Cretaceous marlstones/ claystones and Quaternary fluvial deposits, while the higher values (higher than c. $20 \Omega \mathrm{m}$ ) in general characterize the basalt dykes and diatreme breccias. The very low values of resistivity (less than $2 \Omega \mathrm{m}$ in the inverted model) mark probably the fault zone (x-coordinates 40-60 in Fig. 8), since fault zones often contain an increased amount of clay particles (e.g., Valenta et al. 2008). The resistivity of less than $2 \Omega \mathrm{m}$ is too low for a fault zone and such values are usually an artefact of the inversion routine.

Taken together, the diatreme is characterized by resistivity values higher than $20 \Omega \mathrm{m}$. Hence, the diatreme most likely lays between the x-coordinates 135 and 380 (on the other hand, we may not exclude the possibility that the maar begins on the x-coordinate of 55 or 60 meters) on the profile 1 and 25-245 meters on the profile 2 . The feeding dyke runs parallel to the profile 1 .

The highest resistivities (more than c. $50 \Omega \mathrm{m}$ ) are the effects of coherent basaltic bodies. An exception might be the NE part of the profile 2, where there is a maximum of resistivities but no distinct maximum of gravity or magnetics. Hence this anomaly corresponds most likely to a poorly-weathered breccia rich in coherent magmatic clasts. A similar case might also be the high-resistivity zone in the centre of the profile 2 (x-coordinates 120 160). The high resistivity area does not have a parallel positive magnetic anomaly and also its gravity response is rather low. Therefore it most likely represents a magmatic clast-rich breccia.

The very low resistivity areas on the top of the diatreme represent probably a highly weathered volcanoclastic material, Quaternary sediments and also the watersaturated zone in the vicinity of the Hnojnice brook.

\subsubsection{Gravity measurements}

The gravity measurements should detect the diatreme infill as a zone of decreased gravitational acceleration (Figs 9b and d). The reason is in the origin of this material because the consolidated sediments are fluffed up by the volcanic explosion. In contrast, the basaltic dykes should show themselves as zones of increased acceleration as the massive basalts lava has higher density than its surroundings.

However, there is no minimum in the centre of the diatreme on the profile 1 (Fig. $9 a-b)$. This is due to the presence of the high-density feeder dyke running parallel 


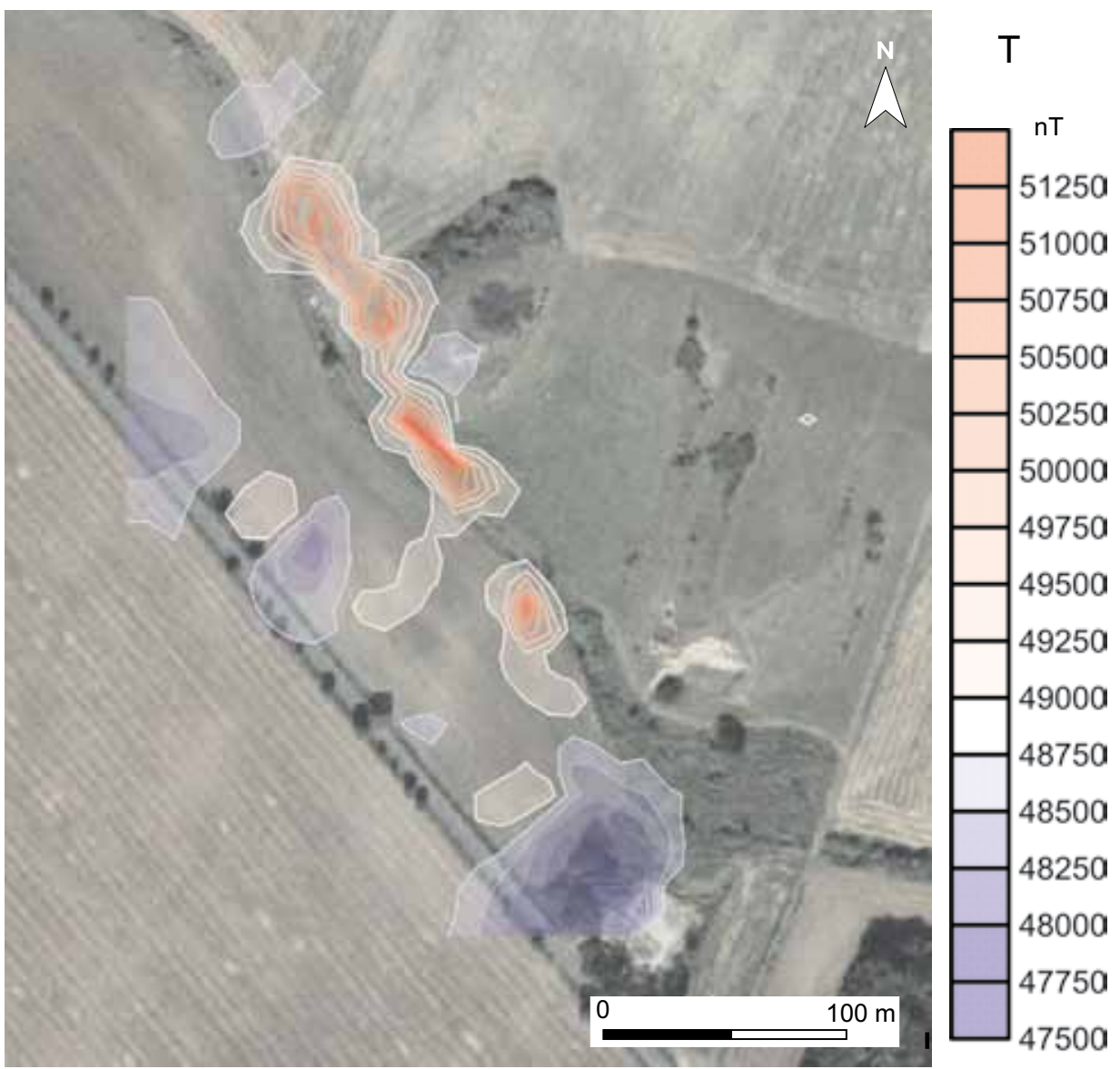

Fig. 7 Magnetic map of the Hnoj nice diatreme.
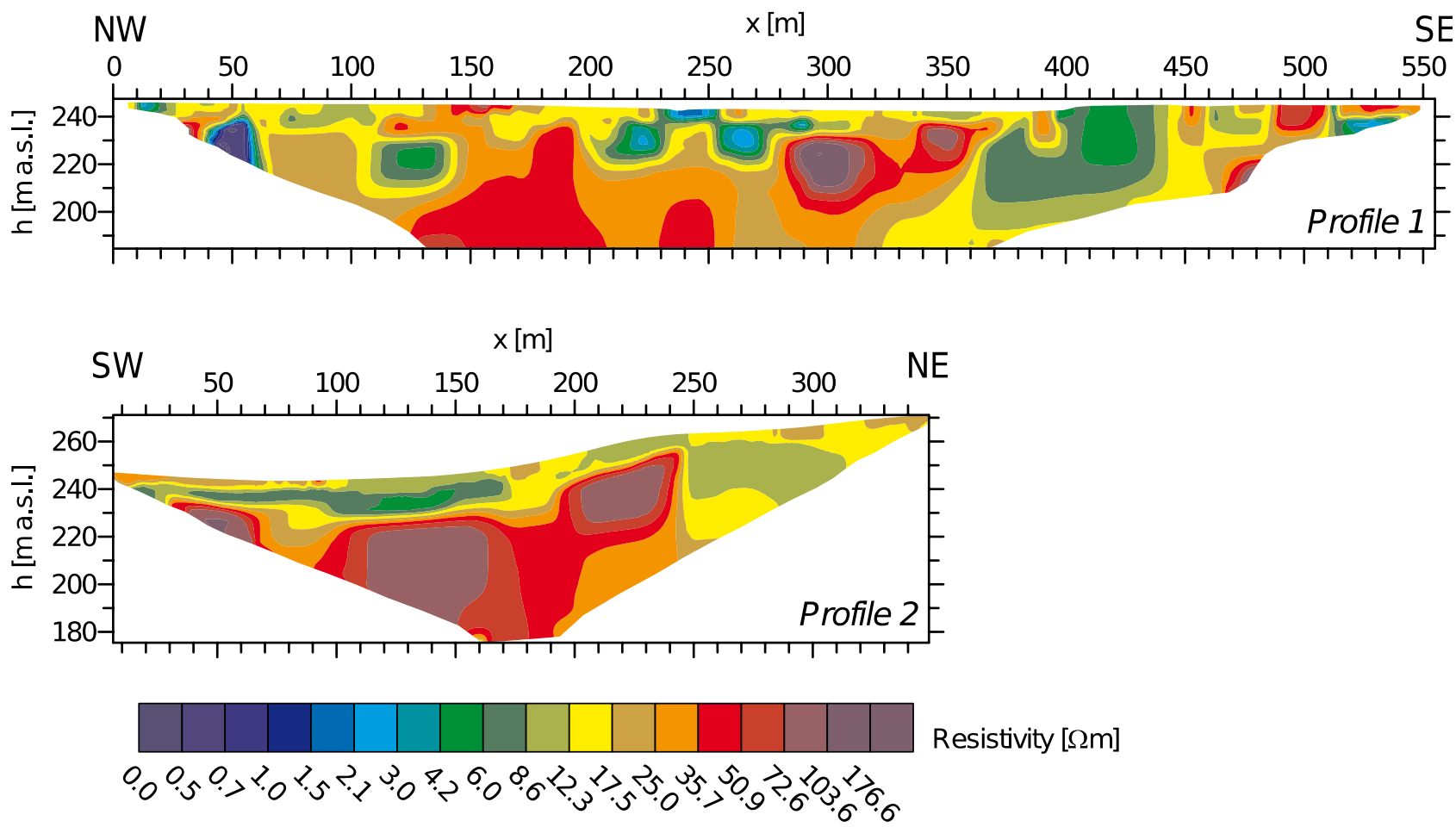

Resistivity $[\Omega \mathrm{m}]$

Fig. 8 2D-inverted multi-electrode resistivity profiles. 
a)

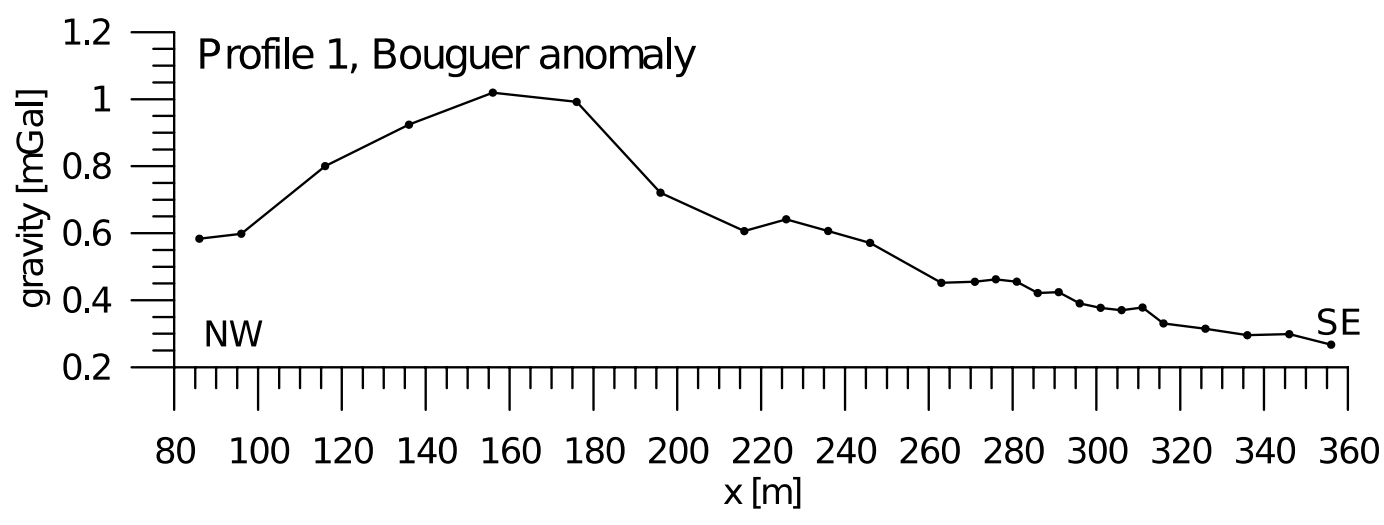

b)

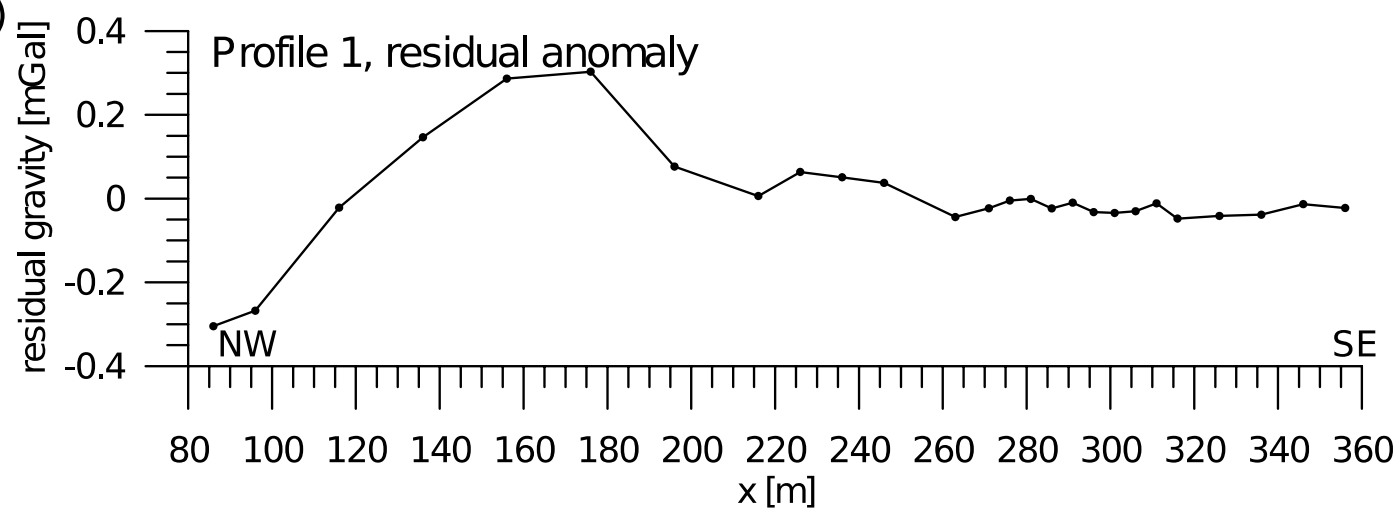

C)

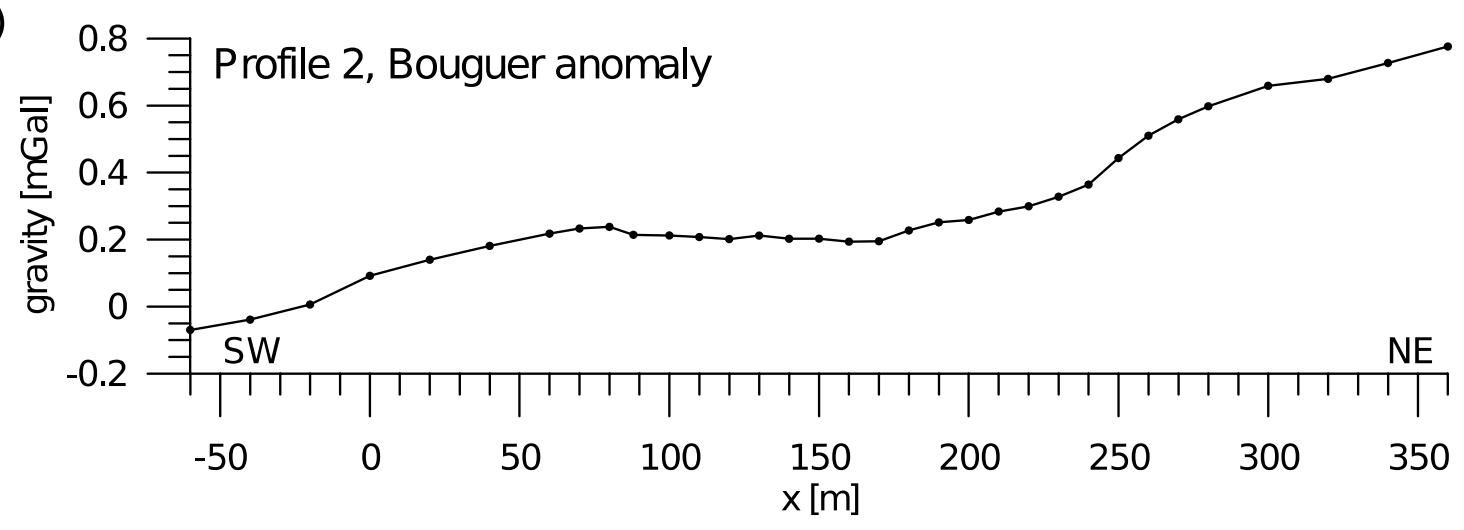

d)

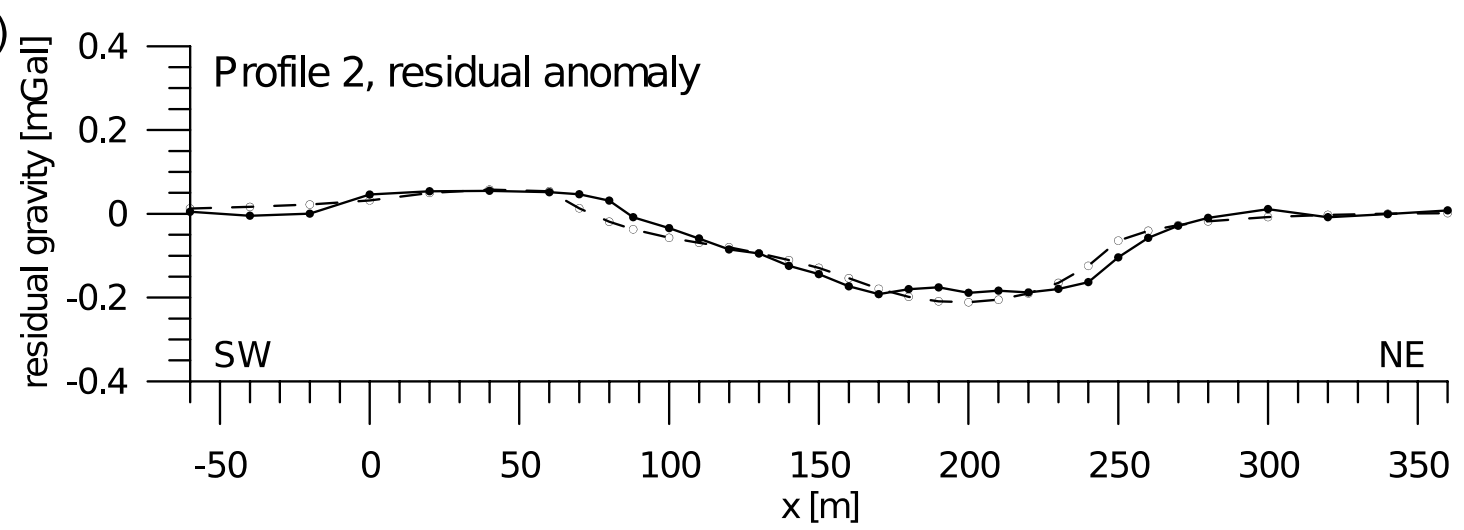

Fig. 9 Gravity measurements. Profile 1: Bouguer anomaly (reduction density $2.4 \mathrm{~g} / \mathrm{cm}^{3}$ ) (a) and residual anomaly (b). Profile 2: Bouguer anomaly (reduction density $2.4 \mathrm{~g} / \mathrm{cm}^{3}$ ) (c) and residual anomaly with calculated gravity curve (dashed line) used for the model on Fig. 10 (d). 
with the profile. Hence the most distinct feature on this profile is the gravity maximum between the $\mathrm{x}$-coordinates 120 and 200. Most likely it marks an irregular shape of the dyke and its thickening in this sector.

The profile 2 (Fig. 9c-d) shows an indistinct, elongated maximum of gravity between the $\mathrm{x}$-coordinates 0 and 90 . It probably corresponds to a set of smaller basaltic dykes concentrated on this side of the diatreme. The gravity-data curve descends very slightly towards the centre of the structure. The slope of the curve is not as steep as would be expected because of the presence of the feeder dyke north of the profile and possibly other thin dykes and magmatic clast-rich breccia between the coordinates 120 and 160 meters (Fig. 9d).

The lack of basaltic dykes in the eastern part of the diatreme makes the gravity anomaly asymmetric and shifted to the east. The eastern rim of the diatreme shows no distinct gravimetric maxima and hence the resistivity maximum at the co-ordinates $200-240$ meters of the profile 2 is most likely caused rather by more compact, less weathered volcanoclastic rocks than by the coherent basaltic rock. The maximum depth of the diatreme may reach about 190 meters according to the gravity survey.

For interpretation of the gravimetric data on the profile 2, a model of the diatreme has been proposed (Fig. 10). The estimated densities used are as follows: $2.4 \mathrm{~g} / \mathrm{cm}^{3}$ for

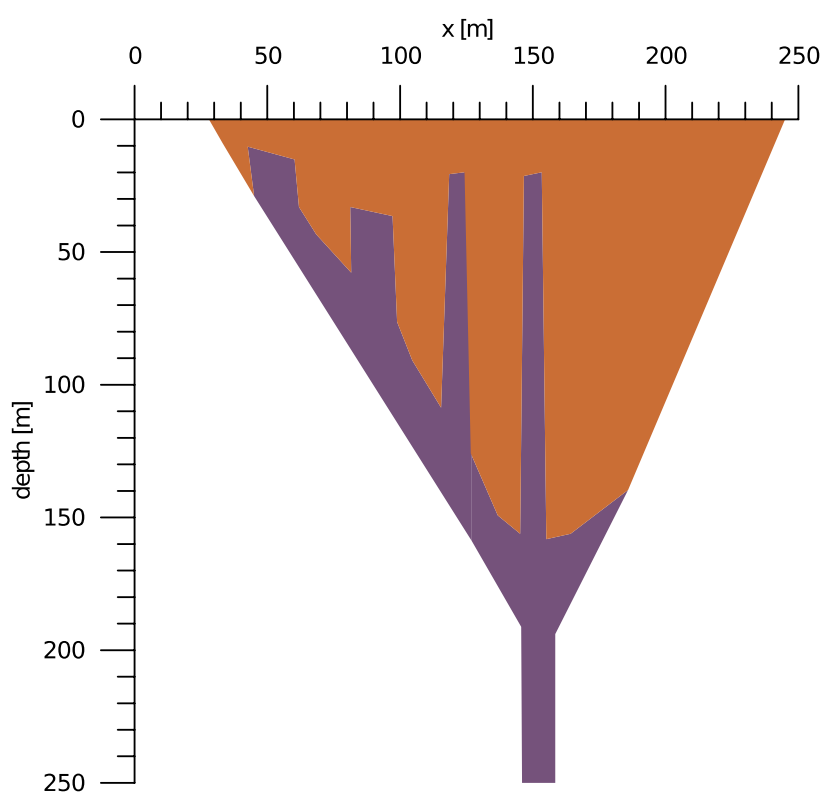

diatreme breccia, relative density $-0.15 \mathrm{~g} / \mathrm{cm}^{3}$ basalt dikes, relative density $0.6 \mathrm{~g} / \mathrm{cm}^{3}$

Fig. 10 Possible theoretical cross-section along the profile 2 based on the gravity data $\left(2.5 \mathrm{D}\right.$ model). The densities assumed are $2.4 \mathrm{~g} / \mathrm{cm}^{3}$ for the surrounding Cretaceous sediments, $2.25 \mathrm{~g} / \mathrm{cm}^{3}$ for the diatreme breccia and $3.0 \mathrm{~g} / \mathrm{cm}^{3}$ for the basaltic dykes. The image of the deepest parts is only an estimate since the gravity data do not yield the resolution needed for a more precise modelling. the Cretaceous country rocks (used also as the reduction density for the Bouguer slab computations), $2.25 \mathrm{~g} / \mathrm{cm}^{3}$ for the diatreme breccia and $3.0 \mathrm{~g} / \mathrm{cm}^{3}$ for the basaltic dykes. The modelled gravity response is plotted in Fig. 9d.

\subsection{Rychnov maar}

\subsubsection{Magnetic measurements}

The contour maps of magnetic and gravity surveys are presented in Fig. 11. The maar area is represented by the negative anomaly $1.5 \times 1.5 \mathrm{~km}$ across both in the gravity and magnetic fields. The crystalline country rock has the magnetic susceptibility of $\sim 250-500 \times 10^{-6} \mathrm{SI}$ and density of $2.67-2.79 \mathrm{~g} / \mathrm{cm}^{3}$, while the breccia filling the crater has the magnetic susceptibility of $\sim 100-160 \times 10^{-6} \mathrm{SI}$ and density of $2.15-2.45 \mathrm{~g} / \mathrm{cm}^{3}$. According to the gravity image, the breccia-filled crater reaches $800 \mathrm{~m}$ in depth.

The negative magnetic anomaly delimitates well the shape of the maar-diatreme volcano to the west and south. The northern and eastern parts are affected by urban construction and therefore no magnetic measurements could be done. Thus we were not able to verify the presence of smaller dyke(s) at the northern margin (Watznauer 1935). There is a distinctive linear local anomaly detected by magnetic field at the southern margin of the structure. It runs in the WNW-ESE direction for some $800 \mathrm{~m}$. The second local maximum is situated in the SE part of the structure. The magnetic image of the maar surroundings is inhomogeneous with local maxima and minima.

\subsubsection{Gravity measurements}

The significant gravity decrease reaches $-6.5 \mathrm{mGal}$ in the central part of the maar. The extent of the anomaly roughly corresponds to the occurrence of thick Cenozoic sediments. The negative gravity anomaly could not be explained solely by a sequence of sediments $c .200 \mathrm{~m}$ thick filling the maar crater. Based on gravimetric data, a presence of diatreme with light breccia of crystalline rocks with volcanic admixture fragmented and fluffed up by the volcanic eruption is supposed. The diatreme might reach down to $600 \mathrm{~m}$ below the sediments (Šrámek et al. 1989).

\subsection{3. $\mathrm{K}-\mathrm{Ar}$ dating}

$\mathrm{K}$-Ar age of the Rychnov maar eruption is given by the dyke penetrating the diatreme fill. The potassium concentration (atomic) was determined at $0.763 \% \mathrm{~K}$. Duplicate analyses of argon have been made (Tab. 1). The $\mathrm{K}-\mathrm{Ar}$ age of $28.36 \pm 1.28 \mathrm{Ma}(1 \sigma)$ is calculated using the mean values. 


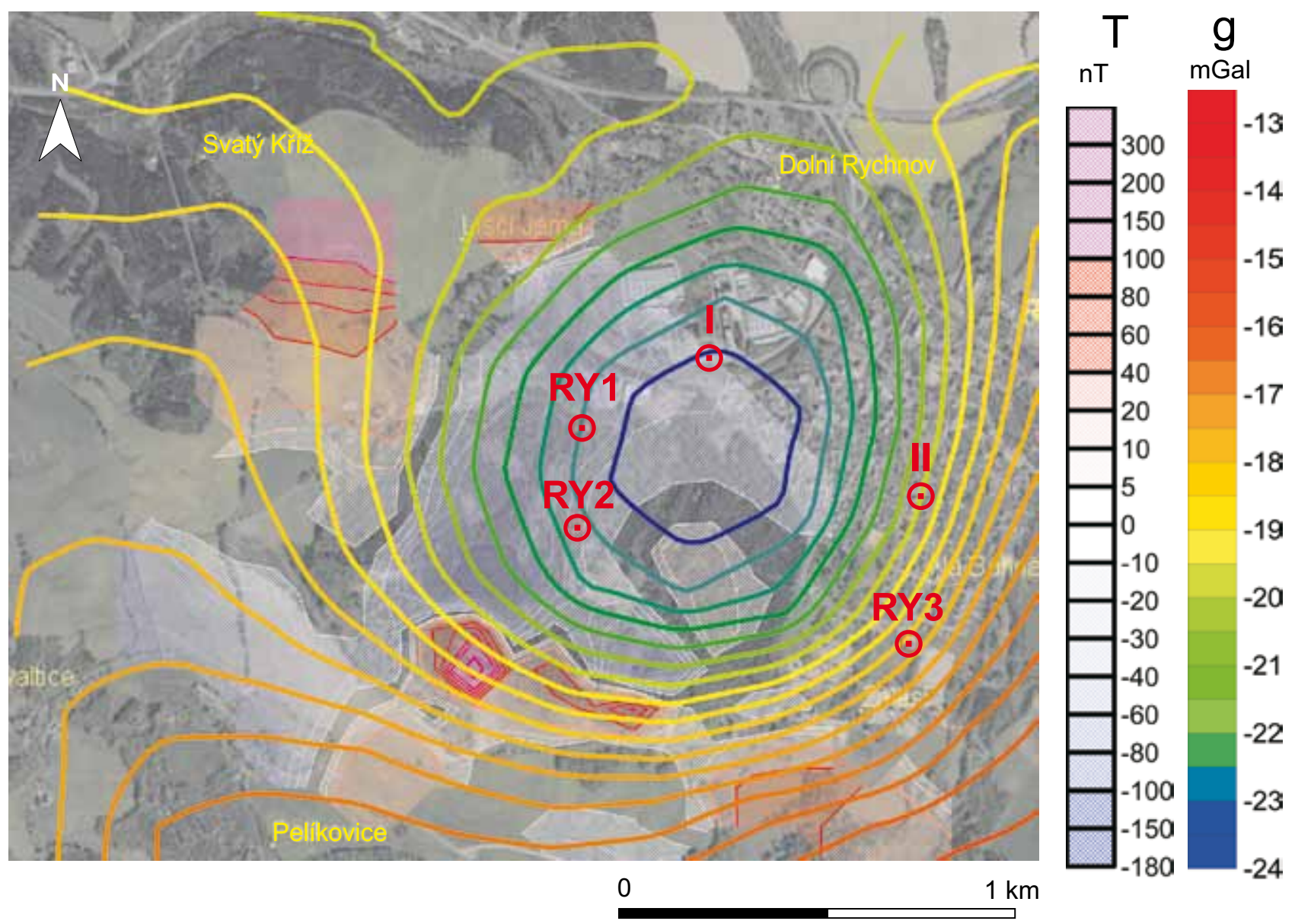

Fig. 11 Magnetic and gravity results in the orthophoto map of the Rychnov maar. Polygons represent variations in magnetic field, contours are used for variations in gravity accelerations; black crosses display points with measurements of magnetic field. Important boreholes from the literature are also indicated.

Tab. $1 \mathrm{~K}-\mathrm{Ar}$ analyses and calculated age of the basaltic dyke penetrating the Rychnov maar

\begin{tabular}{lccc}
\hline & $\operatorname{ccSTP~of~}^{40} \mathrm{Ar}_{\mathrm{rad}}$ & ${ }^{40} \mathrm{Ar}_{\mathrm{rad}}(\%)$ & $\mathrm{K} / \mathrm{Ar}$ age (Ma) \\
\hline measurement 1 & $8.4042 \times 10^{-7}$ & 32.1 & $28.11 \pm 1.32$ \\
measurement 2 & $8.5516 \times 10^{-7}$ & 33.8 & $28.60 \pm 1.30$ \\
average & $\mathbf{8 . 4 7 7 9} \times \mathbf{1 0}^{-7}$ & $\mathbf{3 2 . 9}$ & $\mathbf{2 8 . 3 6} \pm \mathbf{1 . 2 8}$ \\
\hline
\end{tabular}

\section{Discussion}

\subsection{Age of studied maar volcanoes}

The Rychnov maar (c. $28 \mathrm{Ma}$ ) is significantly older than other monogenic volcanoes in the Lusatian Fault area (c. $17 \mathrm{Ma}$ - Rapprich et al. 2007; Cajz et al. 2009b), but the Cenozoic volcanic activity in the Bohemian Massif culminated in Early Oligocene. The age of the Rychnov maar can be compared with similar ages dating the main activity in the CSVC (Cajz 2000) or with volcanism in Poland (Birkenmajer and Pécskay 2002; Birkenmajer et al. 2004). The shape of the maar was probably preserved because of the hard crystalline rocks within which it is situated.

The age of the Hnojnice maar could not be determined analytically. At the southwestern margin of the CSVC, monogenic volcanoes of the Tortonian and Burdigalian age occur (Cajz et al., 2009a). The Late Miocene volcanic edifices are typically only slightly affected by erosion, whereas products of the Oligocene and Early Miocene volcanic activity are deeply eroded and altered. This means that the remnants of maar-diatreme volcanoes of the older age tend to be eroded down to the lower diatreme facies or root zone breccia. Upper diatreme facies were not observed in these cases. On this basis, we suppose that the Hnojnice maar belongs to the youngest, Late Miocene volcanic activity.

\subsection{Structure of studied maar volcanoes}

The elongated positive magnetic anomaly in the Hnojnice diatreme is triggered by the coherent mafic volca- 
NE

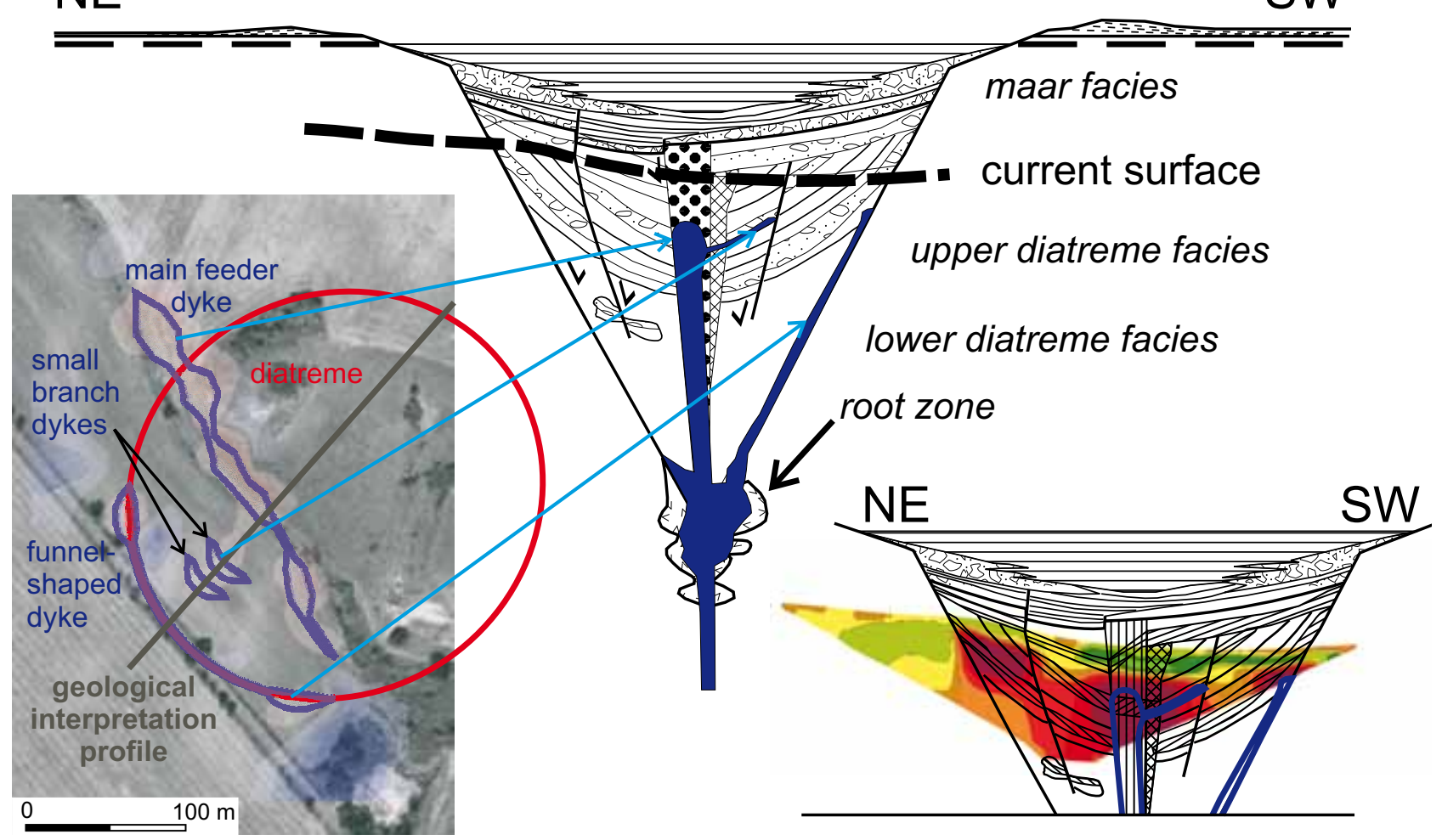

Fig. 12 Interpretation of the geophysical data on the Hnojnice diatreme.

nic rocks, most probably the feeder dyke of the maar eruption. The dyke is parallel to the Hnojnice brook, its straight trend suggests that it follows a NW-SE trending fracture. Such a fracture would correspond to NW-SE trending faults described from this area by Rajchl et al. (2009). This main feeder dyke is well documented also by the geoelectric profile 2, but the profile 1 runs along the dyke or on its top. The main feeder dyke is not well documented by gravity survey as the profile 1 goes along the dyke and the profile 2 has possibly crossed the dyke in a segment of reduced thickness resulting in a weak gravity signal.

The small appendix of positive magnetic anomaly in the central part of the Hnojnice diatreme might be related to a small shallow intrusion branching off from the main feeder dyke. A small branch was also detected by the profile 2, both in electric resistivity and gravity measurements.

The small isolated magnetic maxima at the western and southern margin of the diatreme might be interpreted as a product of thicker segments of a funnel-shaped ring dyke surrounding the diatreme. The presence of inclined coherent basaltic body at the southwestern rim of the diatreme has been also detected by gravity and geoelectric profile 2. The simplified geological model (2.5D) along the profile 2, based on all geophysical methods applied, is in Fig. 12.

The WNW-ESE trending anomaly at the southern rim of the Rychnov maar corresponds to a basanitic dyke, which was exploited by an abandoned quarry in its eastern part. Basanite has a high magnetic susceptibility, reaching $13000 \times 10^{-6}$ SI. The dyke is $\sim 0.8 \mathrm{~km}$ long and its maximum thickness is indicated in the western part, newly discovered by the magnetic survey. The dyke trends parallel to the Lusatian Fault, which might have been responsible for the ascent of the magma feeding the Rychnov volcano.

The second local maximum situated in the SE part of the structure may be explained in two ways:

(1) It may represent a small deep source $(c .800 \mathrm{~m})$ of basaltic intrusion in the root zone of the maar-diatreme. Such a basaltic intrusion might correspond to the basaltic rock encountered by the II borehole (Watznauer 1935).

(2) Alternatively, it may reflect accumulation of metabasaltic clasts in the breccias near the surface.

The geometry of the studied diatremes is reconstructed from geophysical data. Hence the models are dependent on data used for calculations. The Hnojnice diatreme could be steeper if the diatreme breccia had higher densi- 
ties (values closer to those of the surrounding Cretaceous sediments) than assumed. Nevertheless, different geophysical images, namely in gravity data, correspond to distinct geometries of the diatremes in both the studied volcanoes (gentle slopes of the Hnojnice diatreme and steep slopes of the Rychnov maar-diatreme). The angle of the diatreme wall is strongly dependent on countryrock hardness (Lorenz 2003). Therefore, the diatreme of the Rychnov maar should be deeper and narrower if compared to the more open diatreme at Hnojnice. Similar features were described from Fekete-hegy area in Hungary by Auer et al. (2007).

\section{Conclusions}

- Both maar structures yield negative gravity anomalies. The basaltic dykes penetrating the diatreme breccia trigger local gravimetrical maxima, obscuring the overall gravity image.

- If set within Cretaceous marine sediments, a small admixture of magmatic clasts in the phreatomagmatic breccia produces slightly elevated magnetic field. In the setting of crystalline rocks with metavolcanic intercalations, the diatreme is associated with magnetic minima. The dykes can be traced as elongated, very pronounced magnetic maxima in all cases.

- The geometry of the diatreme is strongly controlled by country rock lithologies.

- The age of the Rychnov maar was determined by $\mathrm{K}-\mathrm{Ar}$ analyses to Late Oligocene $(28.4 \pm 1.3 \mathrm{Ma})$.

- The age of the Hnojnice maar was interpreted (based on analogies with surrounding monogenic volcanoes) to Late Miocene (Tortonian). Further analytical work has to be done on a suitable sample.

Acknowledgements. The geophysical research on Hnojnice maar has been financed by the project IAA300460602 of the Grant Agency of the Czech Academy of Sciences (GAAV). The study on the Rychnov maar has been supported by the project $\mathrm{VaV} \mathrm{SP/2e6/97/08}$ of the Czech Ministry of Environment. The study was held within the framework of the research plans of the Czech Geological Survey (MZP0002579801) and the Institute of Rock Structure and Mechanics AS CR, v.v.i. (AVOZ30460519). Our thanks are addressed to Peter Suhr and an anonymous reviewer for constructive comments and suggestions as well as to handling editor Václav Kachlík and editor-in-chief Vojtěch Janoušek for careful handling and hunting for all bugs. Special thanks are due to Mr. V. Záborec, who kindly allowed us to make several geophysical profiles on his grounds at Hnojnice.

\section{References}

Auer A, Martin U, Németh K (2007) The Fekete-hegy (Balaton Highland Hungary) "soft-substrate" and "hard-substrate" maar volcanoes in an aligned volcanic complex - implications for vent geometry, subsurface stratigraphy and the palaeoenvironmental setting. J Volcanol Geotherm Res 159: 225-245

BALOGH K (1985) K/Ar dating of Neogene volcanic activity in Hungary: experimental technique, experiences and methods of chronologic studies. ATOMKI Rep. D/1: 277-288

Birkenmajer K, Pécskay Z (2002) Radiometric dating of the Tertiary volcanics in Lower Silesia, Poland. I. Alkali basaltic rocks of the Opole region. Bull Polish Acad Sci, Earth Sci 50: 31-50

Birkenmajer K, Pécskay Z, Grabowski J, Lorenc MW, ZAGOZDZON PP (2004) Radiometric dating of the Tertiary volcanics in Lower Silesia, Poland. IV. Further K-Ar and palaeomagnetic data from Late Oligocene to Early Miocene basaltic rocks of the Fore-Sudetic Block. Ann Soc Geol Pol 74: 1-19

BrunNer I, Friedel S, Jacobs F, Danckwardt E (1999) Investigation of a Tertiary maar structure using three dimensional resistivity imaging. Geophys J Int 136: 771-780.

BuReš V, Fiedler M, Hanuš L (1973) Josefův Důl dam - $1^{\text {st }}$ phase. Mould deposits - Rychnov nad Nisou. Josefưv Důl dam project. Unpublished report, archive of the Czech Geological Survey - Geofond, pp 1-34 (in Czech)

CAJZ V (2000) Proposal of lithostratigraphy for the České středohoří Mts. volcanics. Bull Czech Geol Surv 75: 7-16

Cajz V, Vokurka K, Balogh K, Lang M, Ulrych J (1999) The České středohoří Mts.: volcanostratigraphy and geochemistry. Geolines 9: 21-28

Cajz V, Rapprich V, Erban V, Pécskay Z, Radoñ M (2009a) Late Miocene volcanic activity in the České středohoří Mountains (Ohře/Eger Graben, northern Bohemia). Geol Carpath 60: 519-533

Cajz V, Rapprich V, Schnabl P, Pécskay Z (2009b) A proposal on lithostratigraphy of Cenozoic volcanic rocks in Eastern Bohemia. Zpr geol výzk za rok 2008: 9-14 (in Czech with English Abstract)

Cassidy J, France SJ, Locke CA (2007) Gravity and magnetic investigation of maar volcanoes, Auckland volcanic field, New Zealand. J Volcanol Geotherm Res 159: $153-163$

COOPER GRJ (2010) Geomodel - simultaneous magnetics and gravity modelling and inversion, Version 2.01. Johannesburg, University of the Witwatersrand. http://web.wits.ac.za/ Academic/Science/GeoSciences/Research/Geophysics/ GordonCooper/Software.htm, visited September $9^{\text {th }} 2010$

ČADEK J, VÁCl J (1959) Final report of the project Basic geological research of the Hrádek segment of the Žitava 
Basin. Unpublished report, archive of the Czech Geological Survey - Geofond (in Czech)

Emilia DA, Last BJ, Wood CA, Dakin FM (1977) Geophysics and geology of an explosion crater in the Ethiopian rift valley. Bull Volcanol 40: 133-140

Fisher RV, Schmincke H-U (1984) Pyroclastic rocks. Springer Verlag, Berlin, pp 1-472

InTERNATIONAL COMMISSION ON STRATIGRAPHY (2010) International Stratigraphic Chart. http://www.stratigraphy.org/ upload/ISChart2009.pdf, visited September $9^{\text {th }}, 2010$.

KАCHLíK V, РАтоČKA F (1998) Lithostratigraphy and tectonomagmatic evolution of the Železný Brod Crystalline Unit: some constraints for the Palaeotectonic development of the W Sudetes (NE Bohemian Massif). Geolines 6: 34-35

KOPECKÝ L (1987) Young volcanism of the Bohemian Massif (structural-geological and volcanological study), part I. Geol hydrometal uran 11(3): 30-67 (in Czech)

KopeckÝ L, Píšová J, PoKornÝ L (1967) Pyrope-bearing diatremes of the České středohoři Mountains. Sbor Geol Věd, Geol 12: 81-130

Lindner H Gabriel G Götze H-J Kaeppler R Suhr P (2006) Geophysical and geological investigation of maar structures in the Upper Lusatia region (East Saxony). Z Dsch geol Gess 157: 355-372

Loera HL, Aranda-Gómez JJ, Arzate JA, Molina-Garza RS (2008) Geophysical survey of the Joya Honda maar (México) and surroundings: volcanic implications. J Volcanol Geotherm Res 170: 135-152

LOKE MH, BARKER RD (1996): Rapid least-squares inversion of apparent resistivity pseudosections using a quasiNewton method. Geophys Prospect 44: 131-152

LORENZ V (2003) Maar-diatreme-volcanoes, their formation and their setting in hard-rock or soft-rockenvironments. Geolines 15: 72-83

LORENZ V (2007) Syn- and posteruptive hazards of maardiatreme volcanoes. J Volcanol Geotherm Res 159: 285-312

LORENZ V, KurszLaukis S (2007) Root zone processes in the phreatomagmatic pipe emplacement model and consequences for the evolution of maar-diatreme volcanoes. J Volcanol Geotherm Res 159: 4-32

LORENZ V, SuHR P, Goth K (2003) Maar-Diatrem-Vulkanismus - Ursachen und Folgen. Die Guttauer Vulkangruppe in Ostsachsen als Beispiel für die komplexen Zusammenhänge. Z Geol Wiss 31: 267-312

Lustrino M, WiLson M (2007) The Circum-Mediterranean Anorogenic Cenozoic Igneous Province. Earth Sci Rev 81: $1-65$

MALKOvSKÝ M (1953) Stone suns. Vesmír 32: 35 (in Czech)

Mrlina J, Kämpf H, Kroner C, Mingram J, Stebich M, Brauer A, Geissler WH, Kallmeyer J, Matthes H, Seidl M (2009) Discovery of the first Quaternary maar in the
Bohemian Massif, Central Europe, based on combined geophysical and geological surveys. J Volcanol Geotherm Res 182: 97-112

RajChl M, UličnÝ D, Grygar R, MaCh K (2009) Evolution of basin architecture in an incipient continental rift: the Cenozoic Most Basin, Eger Graben (Central Europe). Basin Res 21: 269-294

RAPPRICH V (2007) Volcanic processes in the surroundings of Kadaň. Zpr geol výzk za rok 2006: 34-36 (in Czech with English abstract)

Rapprich V, Holub FV (2008) Geochemical variations within the Upper Oligocene-Lower Miocene lava succession of Úhošt' Hill (NE margin of Doupovské hory Mts., Czech Republic). Geol Quart 52: 253-268

Rapprich V, Cajz V, KošŤák M, Pécskay Z, Ř́ídKošil T, RAŠKA P, RADOŇ M (2007) Reconstruction of eroded monogenic Strombolian cones of Miocene age: a case study on character of volcanic activity of the Jičín Volcanic Field (NE Bohemia) and subsequent erosion rates estimation. J Geosci 52: 169-180

Schulz R, Buness H, Gabriel G, Pucher R, Rolf C, WieDERHOLD H, WonIK T (2005) Detailed investigation of preserved maar structures by combined geophysical surveys. Bull Volcanol 68: 95-106

Š́nÁMEK J, TOMEK Č, RYChTÁR J (1989) Detailed gravity survey of the southern margin of Krkonoše-Jizera Pluton and the surrounding crystalline units. Čas Mineral Geol 34: 181-194 (in Czech)

Steiger RH, JäGER E (1977) Subcommission on Geochronology: convention on the use of decay constants in geoand cosmochronology. Earth Planet Sci Lett 36: 359-362

SuHR P (1999) Phreatomagmatic structures in the northern environs of the Ohře Rift (Saxony). Geolines 9: 119-122

Ulrych J, PiveC E (1997) Age-related contrasting alkaline volcanic series in North Bohemia. Chem Erde 5: 311-336

Ulrych J, Pivec E, Lang M, Balogh K, Kropáček V (1999) Cenozoic intraplate volcanic rock series of the Bohemian Massif: a review. Geolines 9: 123-135

Ulrych J, Svobodová J, Balogh K (2002) The source of Cenozoic volcanism in the České středohoří Mts., Bohemian Massif. Neu Jb Mineral, Abh 177: 133-162

Valenta J, Stejskal V, ŠTĚPančíková P (2008) Tectonic pattern of the Hronov-Porríčí trough as seen from poledipole geoelectrical measurements. Acta Geodyn Geomater 5: 185-195

VANĚČKová M, Holub F V, Souček J, Bowes DR (1993) Geochemistry and petrogenesis of the Tertiary alkaline volcanic suite of the Labe Tectonovolcanic Zone, Czech Republic. Mineral Petrol 48: 17-34

Watznauer A (1935) Die Geologie des Bezirkes Gablonz. Heimatkunde des Bezirkes Gablonz in Böhmen. Gablonz-Tanwalder Lehrerverein, pp 1-117 